\title{
ANALISIS PENGARUH KEPERCAYAAN TERHADAP KEPUTUSAN PELANGGAN MENGGUNAKAN PRODUK IM3 DIKALANGAN MASYARAKAT KOTA LHOKSEUMAWE
}

\author{
TEUKU EDYANSYAH
}

Fakultas Ekonomi dan Bisnis Universitas Malikussaleh, Lhokseumawe

The purpose of this study was to determine the effect of trust in the customer's decision to use the product IM3 in Lhokseumawe City. The population in this study is that people who use the product IM3 in Lhokseumawe City as a cellular telecommunications network. Because the population is not so clear in use IM3 products, the researchers took a sample of 100 respondents. The data obtained will be calculated and analyzed according to the model that are related. To see the effect, the authors use a simple linear regression model to see how much influence the customer's trust in the costumer decision. Used in this study also tested the validity and reliability testing as well as the classical assumption of normality test and test heteroscedasticity. From the research, to find how many the role of trust (X) in influencing customer decisions (Y), can be seen in the R2 value of 0.408 or $40.8 \%$ and the remaining 59.2 $\%$ is influenced by other variables not examined in this study (error term). T test or ttest for independent variable (X) obtained tcount 8.222 , so the value of tcount $8.222>$ ttabel 1.984, where that trust in costumer $(\mathrm{X})$ significantly influence customer decision variable $(\mathrm{Y})$ with a significant level of 0.000 . So it can be concluded that in this study received a hypothesis (H1) proposed that independent variables significantly influence customer decisions. Advice from the results of this study are encouraging consumer confidence in the IM3 level of sales that the company should continue to give satisfaction on an ongoing basis so that the percentage of sales in its services continues to increase.

Keywords: Confidence, Customer Decision 


\section{PENDAHULUAN}

Teknologi komunikasi saat ini tidak hanya menjadi kebutuhan masyarakat umum tetapi juga menjadi ladang bisnis yang prospektif. Bisnis operator selular dari tahun ke tahun terus meningkat seiring perkembangan jaman. Selain itu, didukung pula dengan hadirnya telepon selular murah yang mampu dijangkau berbagai lapisan masyarakat hingga bisnis operator selular pun makin menjamur di Indonesia. Pergerakan pasar telepon seluler ini sudah merambah kalangan masyarakat bawah. Ini bisa dengan mudah dijumpai karena para pengojek hingga tukang sayur telah memanfaatkan telepon selular. Mungkin inilah hasil manis dari diberlakukannya Undang-Undang RI no.36/1999 tentang Telekomunikasi yang memberikan pondasi bagi kompetisi pasar telekomunikasi di Indonesia.

Pasar bisnis seluler di Indonesia tampaknya memang tergolong menggiurkan. Tak heran jika para pelaku usaha bisnis seluler ini begitu agresif dalam memperebutkan pasar. Terlebih lagi dengan masih rendahnya teledensitas, regulasi yang masih tergolong longgar hingga budaya lisan masyarakat Indonesia menjadi indikator empuknya bisnis ini (www.businesjournal.co.id).

Perubahan operator selular tergolong pesat di Indonesia. Kalau dibagi berdasarkan platform yang digunakan, pemakai GSM selular sebanyak 88\%, CDMA selular 3\%, dan CDMA fixed wireless access (FWA) 9\%. Namun dari sepuluh operator itu hanya 3 operator yang memiliki pangsa pasar lebih dari 5\% yaitu Telkomsel, Indosat dan Excelcomindo. Berdasarkan Kajian Nathan dan Amitra, kompetisi di telepon selular telah terjadi lebih intensif. PT. Telkomsel dan PT. Indosat memiliki cakupan nasional, sedangkan Excelcomindo memiliki cakupan hampir di seluruh wilayah kecuali Maluku, dan Fren dari Mobile-8 hanya terdapat di pulau Jawa, Madura dan Bali. Untuk produk dari PT Indosat sendiri pada kuartal 1tahun 2016 telah mencapai angka 39,1 juta. Angka ini naik sekitar 17,6 persen atau bertambah hampir 6 juta pelanggan jika dibandingkan kuartal yang sama tahun 2015 lalu (www.wordpress.com).

Prestasi PT Indosat Tbk pun tak dapat diragukan lagi dalam perjalannya sebagai salah satu operator seluler terbesar di Indonesia. PT indosat Tbk kembali meraih 11 penghargaan untuk Contact Center-nya dalam ajang The Best Contact Center Indonesia 2009. The Best Contact Center Indonesia merupakan apresiasi bagi para praktisi contact center terbaik Indonesia bagi individu dan juga korporat yang diselenggarakan oleh Indonesia Contact Center Association (ICCA).

Salah satunya produk dari PT Indosat adalah IM3 yang terkenal sebagai raja operator selular di segmen anak muda dan IM3 menguasai 2/3 dari total pelanggan Indosat. PT Indosat memang memfokuskan pasarnya untuk anak muda.pasar anak muda merupakan pasar seluler terbesar kedua setelah pasar pekerja. Dari total populasi, segmen pasar ini jumlahnya mencapai 35\%. Walaupun mereka belum memiliki penghasilan sendiri, faktanya daya beli segmen pasar ini tergolong tinggi. Pada umumnya karakter anak muda, mereka ,mau melakukan apa saja untuk menopang gaya hidupnya.

Namun peribahasa "ada uang ada barang" nampaknya juga berlaku pada IM3. Tarif yang murah dan fitur canggih yang lengkap tak menjadikan IM3 selalu mampu memuaskan hati pada pelanggannya. Banyaknya keluhan pelanggan membuat IM3 terkadang terperosok paada motto yang dibuat oleh Indosat sendiri yaitu "Sinyal Kuat Indosat" karena pada kenyataannya memang sinyal Indosat dan terutama IM3 bisa dibilang sangat buruk dibanding para pesaingnya. Sinyal IM3 terkadang hilang pada saat musim hujan dan terutama pada Hari Raya Lebaran dimana aktivitas seluruh operator selular sangat padat.

Persaingan yang semakin ketat dan semakin berkembangnya ekspektasi pelanggan mendorong perusahaan untuk lebih memfokuskan pada upaya untuk mempertahankan pelanggan yang ada Mempertahankan pasar yang ada melalui pengembangan kepuasan pelanggan merupakan tujuan strategik perusahaan untuk mempertahankan bisnis dan profit mereka (Rully, 2006).

Kepuasan pelanggan merupakan suatu ukuran keterikatan konsumen terhadap sebuah merk. Ukuran ini mampu memberikan gambaran tentang mungkin tidaknya pelanggan beralih ke produk yang lain. Banyak faktor yang mempengaruhi kepuasan pelanggan misalnya product quality 
(kualitas produk), service quality (kualitas pelayanan), product design (desain produk), price (harga), dan trust (kepercayaan).

Saat ini peneliti memperkirakan bahwa banyak pelanggan IM3 yang memilih menggunakan produk IM3 tersebut karena pertimbangan harga yang lebih murah dengan berbagai fasilitas tambahan yang diberikan kepada para pelanggannya. Namun, pada sisi yang lain masih terdapat sejumlah kekurangan, dibidang pelayanan misalnya; dibeberapa kawasan tertentu sinyal IM3 masih lemah. Keputusan pelanggan merupakan suatu ukuran keterikatan konsumen terhadap sebuah merek. Ukuran ini mampu memberikan gambaran tentang mungkin tidaknya pelanggan beralih ke produk yang lain. Banyak faktor yang mempengaruhi keputusan pelanggan misalnya product quality (kualitas produk), service quality (kualitas pelayanan), product design (desain produk), price (harga) dan trust (kepercayaan). Namun pada kali ini peneliti mencoba mengambil satu dari lima variabel yang mempengaruhinya yaitu trust (kepercayaan).

Dari segi kepercayaan, yang merupakan salah satu unsur penting dalam keputusan pelanggan. Spekman (2008) mengemukakan betapa pentingnya trust (kepercayaan) bagi perdagangan karena hubungan yang terjadi dicirikan oleh adanya kepercayaan yang tinggi sehingga pihak-pihak yang berkepentingan akan berkeinginan untuk melaksanakan komitmen mereka demi hubungan kerjasama yang sukses membutuhkan kepercayaan, saling menghormati dan menghargai, komunikasi yang baik serta kerelaan untuk berbagi dengan mitranya.

Hasil penelitian terhadap keputusan pelanggan telah banyak dilakukan. Melalui riset ini akan dianalisis mengenai kepercayaan yang mempengaruhi keputusan pelanggan menggunakan IM3. Perilaku pelanggan untuk tetap setia menggunakan IM3 karena fitur-fitur yang ditawarkan IM3 sangat menarik pelanggan baik pada segmennya yaitu kawula muda maupun kalangan pekerja atau bahkan eksekutif. Namun dengan adanya kekurangan sinyal yang lemah dan masih dirasakan oleh banyak pengguna IM3 pada jangkauan daerah yang jauh dari perkotaan membuat pelanggan masih belum merasa puas walau fitur yang di- tawarkan sangat murah dari pesaing-pesaing lainnya. Sebenarnya pelanggan yang puas terhadap performa sebuah produk akan mendorong pelanggan untuk melakukan pembelian ulang dan menciptakan suatu sikap loyal pada produk tersebut. Sejalan dengan hal di atas, peneliti tertarik untuk meneliti apa saja yang menyebabkan pelanggan tetap setia pada produk IM3 meskipun kualitas sinyal IM3 masih dibilang kalah dibandingkan para pesaingnya, hal itulah yang menjadi fenomenal penelitian ini.

Berdasarkan latar belakang penelitian diatas, maka dapat dirumuskan masalah yaitu bagaimanakah pengaruh kepercayaan terhadap keputusan pelanggan menggunakan produk IM3 dikalangan masyarakat Kota Lhokseumawe?

\section{STUDI KEPUSTAKAAN}

\section{Manajemen Pemasaran}

Menurut American Marketing Association (AMA) yang dikutip oleh Kotler dan Keller (2007) yang diterjemahkan oleh Benyamin Molan, mendefinisikan manajemen pemasaran adalah seni dan ilmu memilih pasar sasaran dan mendapatkan, menjaga, dan menumbuhkan pelanggan dengan menciptakan, menyerahkan, dan mengomunikasikan nilai pelanggan yang unggul.

Ada empat filosofi persaingan yang secara kuat mempengaruhi suatu aktivitas manajemen pemasaran (Hair, 2001), sebagai berikut :

1. Orientasi Produksi. Suatu filosofi yang berfokus pada kemampuan internal perusahaan yang melebihi dari keinginan dan kebutuhan pasar.

2. Orientasi Penjualan. Pendapat bahwa orang akan membeli barang dan jasa yang lebih baik jika menggunakan tekhnik penjualan yang agresif dan penjualan yang tinggi tersebut akan mendatangkan keuntungan yang tinggi pula.

3. Orientasi Pasar. Filosofi yang menganggap bahwa suatu penjualan tidak bergantung pada sebuah penjualan yang agresif tetapi lebih pada keputusan pelanggan untuk membeli produk.

4. Orientasi Sosial. Suatu organisasi ada tidak hanya untuk memuaskan kebutuhan dan keinginan pelanggan saja serta memenuhi tujuan 
organisasi tetapi juga untuk melindungi atau untuk mempertinggi kepentingan yang terbaik atas ondividu dan masyarakatnya dalam jangaka panjang.

\section{Kepercayaan Pelanggan}

Kepercayaan merupakan keyakinan satu pihak mengenai maksud dan perilaku pihak yang lainnya. Dengan demikian kepercayaan konsumen didefinisikan sebagai harapan konsumen bahwa penyedia hasa dapat dipercaya atau diandalkan dalam memenuhi janjinya (Sirdesmukh, 2002). Ganesan (2003) menyebut kepercayaan sebagai kredibilitas. Dalam penelitiannya mengartikan kredibilitas sebagai sejauh mana pembeli percaya bahwa pemasok memiliki keahlian untuk melakukan aktivitas secara efektif dan andal. Menurut Ganesan (2003) kepercayaan berhubungan dengan niat perusahaan untuk mengandalkan mitra pertukaran mereka. Ganesan (2003) menjelaskan bahwa kepercayaan sebagai sebuah kebajikan, karena didasarkan pada sejauh mana perusahaan percaya bahwa mitranya memiliki niat dan motif-motif yang menguntungkan.

Namun menurut Dwyer (2000) kepercayaan antar perusahaan tidak terjadi secara otomatis. Pengalaman dengan perusahaan mitralah yang akan menciptakan kepercayaan. Oleh karena itu untuk mendapatkan sebuah hubungan yang saling percaya dan mendapatkan sebuah reputasi keterpercayaan diperlukan sebuah strategi yang disengaja untuk bersabar dengan pandangan hasil yang akan diperoleh di masa depan, serta akumulasi bukti-bukti mengenai perilaku yang tidak-ingkar. Bahwa kepercayaan melibatkan pembelajaran dan proses relajar tersebut hanya selesai ketika orang yang dipercaya memiliki kesempatan untuk mengkhianati kepercayaan tetapi ia tidak mengambilnya.

Dengan demikian seperti yang dikatakan oleh Morgan dan Hunt (2005) kepercayaan pada dasarnya adalah komponen sentral dalam semua hubungan pertukaran. Dwyer (2000) berpendapat bahwa kepercayaan penting karena menyediakan dasar untuk kerjasama di masa depan. Setelah kepercayaan dibangun, kedua perusahaan belajar bahwa koordinasi, serta upaya-upaya kerjasama akan memberikan hasil yang melebihi apa yang perusahaan akan mencapai jika bertindak semata-mata yang terbaik untuk diri-sendiri. (Anderson, 2004).

Perusahaan yang memiliki reputasi yang baik yaitu yang iklan-iklannya cenderung dipercaya oleh audiens, masyarakat cenderung lebih mudah menerima merek perusahaan, demikian pula logo perusahaan juga lebih mudah dikenali, dan pada gilirannya konsumen menjadi lebih loyal (Herbig, 1994). Sementara itu hasil penelitian dari Taylor (2003) menunjukkan bahwa kepercayaan memiliki pengaruh positif terhadap sikap konsumen.

\section{Tahap-Tahap Pengambilan Keputusan}

1. Pengenalan kebutuhan (need recognition),

Proses dimulainya saat memilih barang atau jasa dengan menyadari adanya banyak pilihan dalam memperoleh kebutuhan yang diinginkan. Kebutuhan ini dapat dipicu oleh rangsangan dari dalam atau dari luar. Rangasangan dari dalam muncul karena seseorang merasakan suatu kebutuhan dari dalam dirinya yang harus dipenuhi, sedangkan rangsangan dari luar muncul karena seseorang terpengaruh oleh faktor diluar dirinya. Penganalisaan keinginan dan kebutuhan yang belum terpenuhi atau tepuaskan. Jika kebuthan tersebut diketahui, maka konsumen akan segera memahami adanya kebutuhan yang belum perlu segera dipenuhi atau masih bisa ditunda pemenuhannya, serta kebutuhan-kebutuhan yang sama-sama harus segera dipenuhi.

2. Pencarian informasi (information search)

Mengumpulkan sebanyak mungkin informasi yang dibutuhkan yang berhubungan dengan kebutuhan yang diharapakan atau diinginkan. Tingkatan pencarian informasi ini dibagi menjadi dua tingkat. Tingkat pertama adalah adanya perhatian yang meningkat dan yang kedua adalah pencarian informasi secara aktif yang dilakukan dengan mencari informasi secara aktif yang dilakukan dengan mencari informasi dari segala sumber. Beberapa pencarian informasi yang dilakukan konsumen tergantung pada kekuatan dorongannya, jumlah informasi yang telah dipunyai, kemudahan dalam memperoleh informasi tambahan, nilai yang ia berikan pada informasi tambahan dan kepuasan yang dia peroleh dari pencarian informasi. 
3. Evaluasi alternatif (evaluation of alternatives) Konsumen memproses informasi tentang pilihan merek untuk membuat keputusan akhir. Konsumen biasanya mengidentifikasi alternatif pembeliannya. Pengindentifikasian alternatif pembelian tersebut tidak dapat terpisah dari pengaruh sumber-sumber yang dimiliki, seperti waktu, uang dan informasi. Ada dua teknik yang digunakan konsumen dalam memilih alternatif produk atau merek, yaitu teknik kompensatori dan teknik nonkompensatori. Teknik kompensatori yaitu teknik yang mengkompensasi (menutupi) atribut yang memiliki skor rendah dengan atribut yang dimiliki skor yang tinggi. Penggunaan teknik kompensatori biasanya dipakai jika konsumen mengambil keputusan dalam situasi keterlibatan tinggi. Konsumen akan mengevaluasi keseluruhan atribut yang dimiliki suatu merek, kemudian memberikan penilaian secara keseluruhan. Jika secara keseluruhan merek A memiliki skor yang lebih tinggi dibanding merek B, maka konsumen akan memilih merek A. Prinsipnya, konsumen tidak kelemahan dari suatu atribut, tetapi apakah atribut yang lemah tersebut dapat ditutupi (dikompensasi) oleh atribut lain yang memiliki kelebihan atau skor yang amat tinggi. Teknik non kompensatori yaitu teknik yang dipakai untuk mencapai keputusan yang memuaskan. Pengambilan keputusan yang memuaskan memungkinkan konsumen mencapai pilihan yang optimal. Model tersebut cocok bagi pengambilan keputusan dengan keterlibatan rendah, karena konsumen tidak perlu mencapai keputusan optimal namun cukup keputusan yang "cukup baik".

4. Keputusan pembelian (purchase decision)

Konsumen menyusun merek-merek dalam himpunan pilihan serta membentuk niat pembelian, dan ia akan menjatuhkan pilihan dengan apa yang ia sukai. Ada dua faktor yang mempengaruhi keputusan pembelian, yaitu sikap atau pendirian orang lain dan situasi yang tidak dapat diantisipasi/tidak diharapkan. Kesukaan seseorang terhadap suatu merek dapat meningkat jika orang yang disenangi juga menyukai merek yang sama. Pengaruh orang lain menjadi kompleks bila beberapa orang yang dekat dengan pembeli mempunyai pendapat yang berlawanan dan si pembeli ingin menyenangkan mereka semua. Konsumen memben- tuk suatu maksud pembelian atas pertimbangan faktor-faktor seperti pendapatan keluarga yang diharapkan, harga yang diharapkan dan mamfaat produk yang diharapkan. Ketika konsumen akan bertindak, faktor situasi yang tidak dapat diantisipasi mungkin terjadi untuk mengubah maksud pembelian tersebut.

Perilaku setelah pembelian (postpurchase behavior), yaitu konsumen akan mengalami dua hal yaitu, akan mengalami tingkat kepuasan dan ketidakpuasan sama sekali. Kepuasan pembelian merupakan fungsi dari seberapa dekat antara harapan pembeli atas produk tersebut dengan daya guna yang dirasakan dari produk tersebut. Semakin besar jarak antara harapan dengan hasil yang dirasakan, semakin besar ketidakpuasan konsumen.

\section{METODE PENELITIAN}

\section{Objek dan Lokasi Penelitian}

Objek dalam penelitian ini adalah masyarakat Kota Lhokseumawe yang menggunakan produk IM3. Untuk memperoleh data yang benar dan terpercaya, maka penulis mengadakan penelitian secara langsung pada lokasi penelitian.

\section{Populasi dan Sampel}

Yang menjadi populasi dalam penelitian ini adalah masyarakat Kota Lhokseumawe yang menggunakan produk IM3 sebagai jaringan telekomunikasi selulernya. Karena jumlah populasi yang tidak begitu jelas dalam menggunakan produk IM3 maka peneliti mengambil jumlah sampel sejumlah 100 orang responden.

\section{Teknik Pengumpulan Data}

\section{Riset kepustakaan (Library research)}

Suatu cara untuk memperoleh data sekunder melalui referensi kepustakaan dengan mempelajari dan mengkaji teori-teori dari sumber-sumber terbitan, serta bahan-bahan penelitian yang diperlukan yang diperoleh dari jurnal dan bukubuku serta karya ilmiah lainnya yang berhubungan dengan penelitian ini.

\section{Riset lapangan (Field research)}

Suatu aktivitas penelitian untuk mencari datadata yang lengkap dan akurat dengan judul yang diteliti. 
Penelitian lapangan yang penulis lakukan adalah dengan terjun langsung kesasaran penelitian yang dijadikan pembahasan dengan cara:

a. Observasi, yaitu dengan melakukan pengamatan langsung terhadap objek yang akan diteliti, dalam hal ini adalah pelanggan yang menggunakan produk IM3 di Kota Lhokseumawe.

b. Wawancara, yaitu dalam mengumpulkan data dan informasi, penulis mewawancarai pelanggan yang menggunakan produk IM3 di Kota Lhokseumawe.

c. Kuesioner (angket), yaitu dengan menyebarkan angket kepada responden yang dijadikan sebagai sampel penelitian.

\section{Definisi Operasional Variabel}

1. Kepercayaan (X) yaitu keyakinan satu pihak mengenai maksud dan prilaku pihak yang lainnya. Dengan demikian kepercayaan konsumen didefinisikan sebagai harapan konsumen bahwa penyedia jasa dapat dipercaya atau diandalkan dalam memenuhi janjinya.

2. Keputusan pelanggan (Y) yaitu proses pemecahan masalah yang diarahkan pada sasaran/ suatu aliran tindakan timbal balik yang berkesinambungan diantara faktor lingkungan, proses kognitif dan efektif, serta tindakan prilaku.

\section{Uji Validitas}

Uji validitas digunakan untuk mengukur sah atau valid tidaknya suatu kuesioner. Adapun kriteria pengambilan keputusan uji validitas instrumen dalam penelitian adalah dengan membandingkan nilai Corrected Item-Total Correlation pada setiap butir pertanyaan dengan nilai $\mathrm{r}$ tabel. Jika nilai Corrected Item-Total Correlation (rhitung) $>$ nilai rtabel dan nilainya positif, maka butir pertanyaan pada setiap variabel tersebut dinyatakan valid. Dan sebaliknya jika Corrected Item-Total Correlation (rhitung) < rtabel dan nilainya negatif, maka butir pertanyaan pada setiap variabel tersebut tidak valid (Ghozali, 2007).

\section{Uji Reliabilitas}

Uji reliabilitas untuk mengukur suatu kuesioner yang merupakan indikator dari variabel atau konstruk. Suatu kuesioner dikatakan reliabel atau handal jika jawaban seseorang terhadap pernyataan adalah konsisten dan stabil dari waktu kewaktu. Pengukuran reliabilitas dapat dilakukan dengan one shot atau pengukuran sekali saja (Ghozali, 2007). Suatu kontruk atau variabel dikatakan reliabel apabila nilai Cronbach Alpha $(\alpha)>$ 0,60 (Ghozali, 2007).

\section{Analisis Regresi Linear Sederhana}

Adapun metode analisis data yang digunakan untuk menjawab hipotesis penelitian yaitu untuk mengetahui pengaruh kepercayaan terhadap keputusan pelanggan menggunakan produk IM3 dikalangan masyarakat Kota Lhokseumawe dengan analisis regresi linear sederhana (regresion analysis) dengan bantuan program software SPSS (Statistical Package for Social Science) dengan persamaan sebagai berikut:

$$
\boldsymbol{Y}=\boldsymbol{a}+\boldsymbol{b} \boldsymbol{X}+\varepsilon \boldsymbol{i}
$$

\section{Dimana:}

$\mathrm{Y}=$ Keputusan Pelanggan

$\mathrm{X}$ = Kepercayaan

a $=$ Konstanta

b = Koefisien Regresi

घi $=$ Error term

\section{Pengujian Hipotesis}

Pengujian secara parsial (uji t) dilakukan untuk mengetahui apakah ada pengaruh variabel independen secara parsial yaitu kepercayaan terhadap variabel dependen yaitu keputusan pelanggan dengan tingkat keyakinan $95 \%(\alpha=5 \%)$. Pengujian ini akan membandingkan hasil perhitungan $\mathrm{t}_{\text {hitung }}$ dengan $\mathrm{t}_{\text {tabel }}$. Adapun kriteria pengujian hipotesis untuk uji t adalah:

1. Jika $\mathrm{t}_{\text {hitung }}>\mathrm{t}_{\text {tabel }}$, maka menolak $\mathrm{H}_{0}$ dan meneri$\mathrm{ma} \mathrm{H}_{1}$, yang berarti kepercayaan secara parsial berpengaruh signifikan terhadap keputusan pelanggan menggunakan produk IM3 dikalangan masyarakat Kota Lhokseumawe.

2. Jika $\mathrm{t}_{\text {hitung }}<\mathrm{t}_{\text {tabel }}$, maka menerima $\mathrm{H}_{0}$ dan menolak $\mathrm{H}_{1}$, yang berarti kepercayaan secara parsial tidak berpengaruh terhadap keputusan pelanggan menggunakan produk IM3 dikalangan masyarakat Kota Lhokseumawe. 


\section{HASIL DAN PEMBAHASAN}

\section{Uji Validitas}

Uji validitas digunakan untuk mengukur sah atau valid tidaknya suatu kuesioner. Suatu kuesioner dikatakan valid jika pertanyaan pada kuesioner mampu untuk mengungkapkan sesuatu yang akan diukur oleh kuesioner tersebut. Mengukur tingkat validitas dapat dilakukan dengan cara membandingkan nilai Product Moment, jika hasilnya menunjukkan $r_{\text {hitung }}>r_{\text {tabel }}$ maka butir pertanyaan tersebut dapat dikatakan valid (Ghozali, 2007).

Tabel 1

Uji Validitas

\begin{tabular}{|c|c|c|c|}
\hline No. & Variabel & $\mathbf{r}_{\text {hitung }}$ & $r_{\text {tabel }}$ \\
\hline 1. & \multicolumn{2}{|c|}{ Kepercayaan $(\mathrm{X})$} & \multirow{7}{*}{0,1966} \\
\hline & $X_{1}$ & 0,788 & \\
\hline & $\mathrm{X}_{2}$ & 0,551 & \\
\hline & $\mathrm{X}_{3}$ & 0,707 & \\
\hline & $\mathrm{X}_{4}$ & 0,719 & \\
\hline & $X_{5}$ & 0,833 & \\
\hline & $\mathrm{X}_{6 .}$ & 0,745 & \\
\hline \multirow[t]{6}{*}{2.} & \multicolumn{2}{|c|}{ Keputusan Pelanggan $(\mathrm{Y})$} & \multirow{6}{*}{0,1966} \\
\hline & $\mathrm{Y}_{\cdot_{1} .}$ & 0,707 & \\
\hline & $\mathrm{Y}_{2}$ & 0,714 & \\
\hline & $\mathrm{Y}_{3 .}$ & 0,700 & \\
\hline & $\mathrm{Y}_{4}$ & 0,732 & \\
\hline & $\mathrm{Y}_{5}$ & 0,589 & \\
\hline
\end{tabular}

Berdasarkan hasil pengujian yang diperoleh, adapun nilai $\mathrm{r}_{\text {tabel }}$ diperoleh dari (degree of freedom) $\mathrm{df}=(\mathrm{n}-2)$, dimana $\mathrm{n}$ merupakan jumlah sampel penelitian, jadi nilai $\mathrm{df}=(100-2)$ maka diperoleh sebesar 98 dengan tingkat signifikan sebesar 0.05, maka diperoleh nilai $r_{\text {tabel }}$ sebesar 0,1966. Dari hasil tabel diatas diperoleh nilai $\mathrm{r}_{\text {hitung }}$ $>r_{\text {tabel }}$, maka dapat disimpulkan bahwa pertanyaan ini semua valid karena memenuhi asumsi uji validitas di mana nilai $r_{\text {hitung }}$ lebih besar dari nilai $r_{\text {tabel }}$.

\section{Uji Reliabilitas}

Reabilitas adalah alat ukur suatu kuesioner yang merupakan indikator dari variabel atau konstruk. Suatu kuesioner dikatakan handal jika jawaban responden terhadap pertanyaan adalah konsisten dari waktu-kewaktu. Suatu konstruk atau variabel dikatakan realible jika memberikan nilai Cronbach Alpha > 0,60 (Ghozali, 2007).

Tabel 2

Uji Reliabilitas

\begin{tabular}{|c|l|c|c|}
\hline No & \multicolumn{1}{|c|}{ Variabel } & $\begin{array}{c}\text { Cronbach } \\
\text { Alpha }\end{array}$ & Keterangan \\
\hline 1 & Kepercayaan $(\mathrm{X})$ & 0,818 & Reliable \\
\hline 2 & $\begin{array}{l}\text { Keputusan } \\
\text { Pelanggan }(\mathrm{Y})\end{array}$ & 0,711 & Reliable \\
\hline
\end{tabular}

Dapat disimpulkan bahwa pengukuran nilai Cronbach Alpha terhadap variabel-variabel penelitian memenuhi asumsi reliabilitas dan dapat dikatakan reliabel.

\section{Hasil Analisis Koefisien Regresi Linear Berganda}

Hasil penelitian dapat dilihat dengan membandingkan nilai signifikan hitung dengan nilai signifikan yang ditetapkan yaitu pada tingkat keyakinan $95 \%$ atau pada tingkat kesalahan (alpha) 0,05. Tabel 3 berikut merupakan pembahasan hasil analisis regresi linear sederhana.

Formula regresi linear berganda untuk hasil analisa ini adalah :

$$
Y=1,581+0,604 X+e
$$

Konstanta (a) sebesar 1,581, hal ini menunjukkan bahwa jika kepercayaan (X) dianggap konstan atau tidak mengalami perubahan, maka keputusan pelanggan (Y) adalah sebesar 1,581. Dan untuk nilai koefisien variabel kepercayaan $(\mathrm{X})$ memi-

Tabel 3

Hasil Pengolahan Data Regresi Linear Sederhana Coefficients $^{\mathrm{a}}$

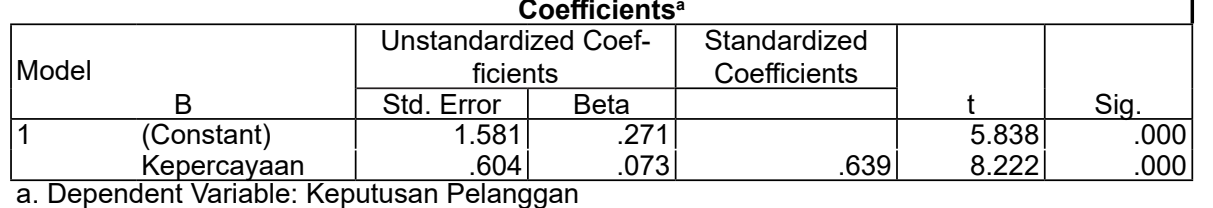


liki nilai sebesar 0,604 yang berarti jika variabel kepercayaan meningkat satu persen, maka akan terjadi peningkatan terhadap keputusan pelanggan (Y) sebesar 0,604 atau $(60,4 \%)$.

\section{Nilai Koefisien Korelasi dan Koefisien Deter- minasi}

Dari pengolahan data penelitian diperoleh nilai koefisien korelasi (R) sebesar 0,639. Ini berarti bahwa hubungan antara kepercayaan (X) terhadap keputusan pelanggan (Y) pada menggunakan produk IM3 dikalangan masyarakat Kota Lhokseumawe mempunyai hubungan sebesar 63,9\%. Dan untuk mengetahui seberapa besar peranan kepercayaan (X) dalam mempengaruhi keputusan pelanggan $(\mathrm{Y})$, dapat dilihat pada nilai $R^{2}$ sebesar 0,408 atau $40,8 \%$ dan sisanya sebesar $59,2 \%$ dipengaruhi oleh variabel lainnya yang tidak diteliti pada penelitian ini (error term).

\section{Pengujian Hipotesis Secara Uji Parsial (Uji t)}

Pengujian hipotesis dilakukan untuk menentukan tingkat signifikansi variabel bebas $(\mathrm{X})$ terhadap variabel terikat (Y) dalam hal ini variabel kepercayaan $(\mathrm{X})$ menggunakan uji $\mathrm{t}$ atau $\mathrm{t}_{\text {test }}$. Untuk nilai $t_{\text {tabel }}$ diperoleh dari $\mathrm{df}=(\mathrm{n}-\mathrm{k}-1), \mathrm{df}=(100-2-1)$ $=97$, dengan tingkat signifikan sebesar 0,05, maka diperoleh nilai $t_{\text {tabel }}$ sebesar 1,984.

Dan untuk uji $t$ atau $t_{\text {test }}$, merujuk pada tabel 4.6, variabel kepercayaan $(\mathrm{X})$ diperoleh nilai $\mathrm{t}_{\text {hitung }}$ senilai 8,222 , jadi nilai $\mathrm{t}_{\text {hitung }} 8,222>\mathrm{t}_{\text {tabel }} 1,984$, dimana bahwa variabel kepercayaan (X) berpengaruh secara signifikan terhadap variabel keputusan pelanggan (Y) dengan tingkat signifikan 0,000. Jadi dapat disimpulkan bahwa dalam penelitian ini menerima hipotesis $\left(\mathrm{H}_{1}\right)$ yang diajukan yaitu variabel kepercayaan berpengaruh signifikan terhadap keputusan pelanggan menggunakan produk IM3 dikalangan masyarakat Kota Lhokseumawe.

\section{KESIMPULAN}

1. Dari hasil penelitian diperoleh nilai koefisien korelasi (R) sebesar 0,639, dimana nilai koefisien korelasi ini terdapat hubungan antara kepercayaan $(\mathrm{X})$ terhadap keputusan pelanggan (Y) yaitu sebesar $63,9 \%$.

2. Untuk nilai koefisien determinasi $\left(\mathrm{R}^{2}\right)$ diper- oleh sebesar 0,408 yang berarti bahwa kepercayaan $(\mathrm{X})$ mempengaruhi keputusan pelanggan (Y) sebesar 40,8\% dan sisanya sebesar $59,2 \%$ dipengaruhi oleh variabel lainnya yang tidak terobsevasi dalam penelitian ini (error term).

3. Untuk uji $t$ atau $t_{\text {test }}$, kepercayaan (X) diperoleh nilai $\mathrm{t}_{\text {hitung }}$ senilai 8,222 , jadi nilai $\mathrm{t}_{\text {hitung }}$ $8,222>\mathrm{t}_{\text {tabel }} 1,984$, dimana kepercayaan $(\mathrm{X})$ berpengaruh secara signifikan terhadap keputusan pelanggan (Y) dengan tingkat signifikan 0,000 .

4. Untuk pengujian secara parsial, dapat disimpulkan bahwa kepercayaan (X) berpengaruh terhadap keputusan pelanggan (Y) menggunakan produk IM3 dikalangan masyarakat Kota Lhokseumawe.

\section{SARAN}

1. Kepercayaan konsumen terhadap IM3 mendorong tingkat penjualan sehingga perusahaan harus terus menerus secara berkesinambungan memberikan kepuasan dalam pelayanannya sehingga persentase penjualan terus meningkat, Tanggapan konsumen atas kepercayaan IM3 dinilai baik, namun lebih diperhatikan pada kehandalan merek yang dimiliki oleh IM3 dimana cukup banyak pesaing-pesaing yang memiliki produk kartu seluler yang lebih terpercaya karena terlebih dahulu muncul, maka dari itu kehandalan dari IM3 harus lebih ditingkatkan lagi sehingga konsumen merasa lebih nyaman dalam menggunakan produk IM3. Perusahaan juga sebaiknya dapat menjaga keputusan pelanggan yang dilakukan konsumen pada pembelian produk IM3 yang sudah dinilai baik, agar terjadi lagi pembelianpembelian selanjutnya. Hal itu bisa dilakukan dengan cara pemotongan harga maupun bonusbonus yang menarik serta program-program yang lainnya untuk menarik oleh konsumen.

2. Pihak perusahaan diharapkan mampu menjaga serta memberikan kepercayaan terhadap konsumen agar keputusan pembelian yang dilakukan oleh konsumen bisa dilakukan secara terus menerus. Namun pada intinya, pelayanan yang baik yang bisa memberikan keny- 
aman pada konsumen merupakan kunci utama dalam keputusan pembelian yang dilakukan oleh konsumen.

3. Peneliti selanjutnya dapat mengembangkan penelitian ini dengan meneliti faktor lain yang dapat mempengaruhi keputusan pelanggan. Peneliti selanjutnya juga dapat menggunakan variabel lain dalam meneliti keputusan pelanggan, misalnya kulitas produk, motivasi untuk membeli, harga produk dan lainnya, sehingga informasi yang diperoleh dapat lebih bervariasi dari hasil penelitian yang telah ada. 


\section{REFERENSI}

Anderson, Narus. (2004). Consumers Behavior And Marketing Action, Edisi 3. Kent Publishing Company, Boston Massachusset, AS. (Jurnal Publikasi)

Cauduri, Holbrook. (2001). Metode Penelitian Manajemen : Pedoman Penelitian Untuk Penulisan Skripsi, Tesis dan Desertasi. BP Undip. Semarang.

Dwyer. F. Robert. (2000). Developing Buyer-Seller Relationship. Jurnal Publikasi.

Engel, James. (2003). Perilaku Konsumen. Jilid 2. Binarupa Aksara. Jakarta.

Genesan, Shankar. (2003). Dasar-Dasar Pemasaran. PT Raja Grafindo Persada. Jakarta.

Ghozali, Imam. (2007). Aplikasi Analisis Multivariate Dengan Program SPSS Edisi 3. BP UNDIP. Semarang.

Hair, Lamb. (2001). Kepercayaan Dan Komitmen Sebagai Perantara Kunci Relationship Marketing Dalam Membangun Loyalitas, Jurnal Riset Ekonomi dan Manajemen Vol.2 No.1. (Jurnal Publikasi)

Herbig. (1994). The Effect of Perceived Service Quality Dimensions On Customer Satisfaction, Trust, And Loyalty in E-commerce Settings. Asia Pasific Journal of Marketing and Logistics. Vol. 22. No. 3. (Jurnal Publikasi)

Kuncoro. (2003). Metode Kuantitatif Teori Dan Aplikasi Untuk Bisnis Dan Ekonomi. Edisi Kedua. UPP AMP YKPN. Yogyakarta.

Kotler, Philip. (1997). Prinsip-Prinsip Pemasaran. Jilid I. Erlangga. Jakarta.

Kotler, Philip, dan Keller, Kevin Lane. (2007). Manajemen Pemasaran. Jilid I PT. Indeks. Jakarta.

Mamaks (2012). Analisis Pengaruh Kepercayaan Pelanggan Dan Kualitas Pelayanan Terhadap Keputusan Pembelian Ulang Pengguna Produk IM3 Di Semarang. Universitas Diponegoro. Semarang.

Mangkunegara, Anwar Prabu. (2002). Perilaku Konsumen. Refika Aditama. Bandung.

Mowen, John C. Dan Michael Minor. (2002). Perilaku Konsumen. Jilid I. Edisi Kelima Erlangga. Jakarta.

Morgan, Robert M. dan Hunt, Shelby D. (2005). The Commitment-Trust Theory Of Relationship Marketing. (Journal of Marketing).

Peter, Paul. J and Olson, C. Jerry. (2000). Perilaku Konsumen Dan Strategi Pemasaran. Cetakan Keempat. Jilid 1. Erlangga. Jakarta. 
Rully. (2006). Pengukuran Tingkat Kepuasan Pelanggan Untuk Menaikkan Pangsa Pasar. Rineka Cipta. Jakarta.

Sirdesmuks. (2002). Riset Pemasaran. Jilid II. Indeks. Jakarta.

Schiffman, Leon G., Leslie Lazar Kanuk. (2000). Consumer Behavior. 7 Edition. Prentice Hall, New Jersey. (Jurnal Publikasi).

Shandi (2011). Analisis Dimensi Kepercayaan Merek, Kredibilitas Merek, Kompetensi Merek Dan Kesukaan Merek Terhadap Loyalitas Merek Pengguna Kartu Indosat IM3 Di Kota Semarang. Universitas Diponegoro. Semarang.

Stanton, W.J. (2001). Prinsip Pemasaran. Jilid II. Erlangga. Jakarta.

Setiadi, Nugroho J. (2003). Perilaku Konsumen : Konsep Dan Implikasi Untuk Strategi Dan Penelitian Pemasaran. Edisi Pertama. Penerbit Prenada Media. Jakarta.

Sugiyono. (2004). Metode Penelitian Bisnis. Alfabenta. Bandung.

Santoso, Singgih. (2005). SPSS Mengolah Data Statistik Secara Profesional. PT. Elex Media Komputindo. Jakarta

Spekman. (2008). Faktor-Faktor Yang Mempengaruhi Keputusan Pelanggan Dalam Penggunaan Produk IM3. http://tentang-pelanggan-kepercyaan.blogspot.com.

Taylor, Hunter. (2003). Manajemen Pemasaran . Erlangga. Jakarta

Tjiptono, Fandy. (2008). Pemasaran Strategik. Andi. Yogyakarta.

http://www.businessjournal.co.id. (Diakses tanggal 5 Januari 2013).

http://www.wordpress.com/operator-seluler-terjebak-dalam-persaingan. (Diakses tanggal 5 Januari 2013) 
